\title{
The Development of Private Higher Education in Nigeria: A Comparative Analysis between Northern and Southern Region
}

\author{
Muhammad Muftahu ${ }^{1}$ \\ ${ }^{1}$ National Higher Education Research Institute, Universiti Sains Malaysia, Malaysia \\ Correspondence: Muhammad Muftahu, National Higher Education Research Institute, Universiti Sains Malaysia, \\ Malaysia.
}

Received: June 1, 2020

Accepted: January 2, 2021

Online Published: January 14, 2021

doi:10.5430/ijhe.v10n3p178

URL: https://doi.org/10.5430/ijhe.v10n3p178

\begin{abstract}
Private higher education is experiencing a rapid considerable growth for decades globally, particularly in Africa. In Nigeria, the history and the development of private higher education precisely universities which is the focus of this paper started 20 years ago with the establishment of Igbinedion University in Okada, Edo State in 1999, followed by two other universities; Babcock University, Ileshan Remo, Ogun State, and Madonna University, Okija, Anambra State in the same year all in the southern part of the country. Comparatively, the American University of Nigeria Yola was established as the first private university in northern region 4 years later. Two years after, another four universities emerged namely Al-hakima University Ilorin, Al-Qalam University Katsina, Bingham University Karu Abuja, and Kwararafa University Wukari Taraba State. As of December, 2020, there are 16 private universities in the northern region with 11 at northcentral, 3 in the northwest, and 2 in the northeast against 63 in the entire southern region comprasing three goe-politcal zones as well. This study intends to critically analyze the trend of these development to identify strategies, practices, and lessons learned between both regions for the spirit of educational development. Consequently, this study revealed the issues and difficulties in promoting private higher education include lack of awareness, lack of human resources, and cost of running in the country as a whole. In line with the identified challenges, the Nigerian government and policymakers are recommended to focus on creating an enabling environment to encourage the establishments of additional private universities more specifically in the northern region.
\end{abstract}

Keywords: private, higher education, universities, Nigeria, comparative analysis

\section{Introduction}

Generally, higher education covers a wide range of higher learning institutions encompassing post-secondary and/or tertiary institutions such as universities, colleges of education, and polytechnics (Alemu, 2018). The concept of higher education is defined as tertiary education and a requirement for preparing professionals, encourage learning, and improve access to knowledge (Mense et al., 2018). Nonetheless, the concept of education has changed significantly over the decades thereby making the boundaries unclear (Turner, 2011). In the contemporary era, universities are considered among the most successful higher education institutions contributing to foster learning and generate knowledge towards achieving educational goals and outcomes (Turner, 2011; Alemu, 2018).

Nigeria is a Federal Republic located in Western Africa and is recognized as the most populous across the African continent (Africa.com, 2019). Hence, Nigeria is known as one of the fastest-growing economies in Africa. In 2018, the country has an estimated total population of 199,441,213 (Africa.com, 2019). In terms of education, the federal government offers free universal basic education but student enrollment is very poor especially in northern Nigeria (Salihu et al., 2015). On higher education, only 583,250 from a total of 1,793,018 higher institutions applicants in Nigeria were accepted into universities, polytechnics, and colleges of education as of 2018 (JAMB, 2019).

\section{Higher Education in Nigeria}

The development history of higher education in Nigeria started over 80 years ago with the establishment of Yaba Higher College in 1932 and University College, Ibadan (UCI) in 1943, which was affiliated to the University of London then (Salihu \& Jamil, 2015). In April 1959, the then colonial government established a commission (popularly known as Ashby commission) to look into the needs of higher education for the soon-to-be independent nation (Fabunmi, 2005). The development of public university education in Nigeria can be summarized into five 
generations. Six first-generation universities were established by 1965 , the second-generation universities were established between 1974 and 1979, the third-generation universities were established between 1979 and 1983, the fourth-generation universities were established between 1988 and 2003, and universities establish between 2003 to date are considered as fifth or new generation universities (Salihu \& Jamil, 2015). Currently, Nigeria operates the 9-3-4 system which denotes that every pupil spends the first 9-years of basic and compulsory education up to the Junior Secondary School (JSS-3) level, another 3 years in the senior secondary school (SSS-3), and 4-years in the tertiary institution's education system, with public universities dominating the country's higher education landscape (Iruonagbe, Imhonopi, \& Eghareva, 2015). According to Abdulraheem and Muhammed (2014), governance issues are viewed as one of the key factors to the unstable structure in Nigerian higher education. The same authors also found other factors contributing to the challenges for efficient governance in Nigerian higher education including funding, political interference, law, and leadership. Accordingly, there are two main types of higher education providers in Nigeria i.e. public and private with various classifications as shown in Figure 1.

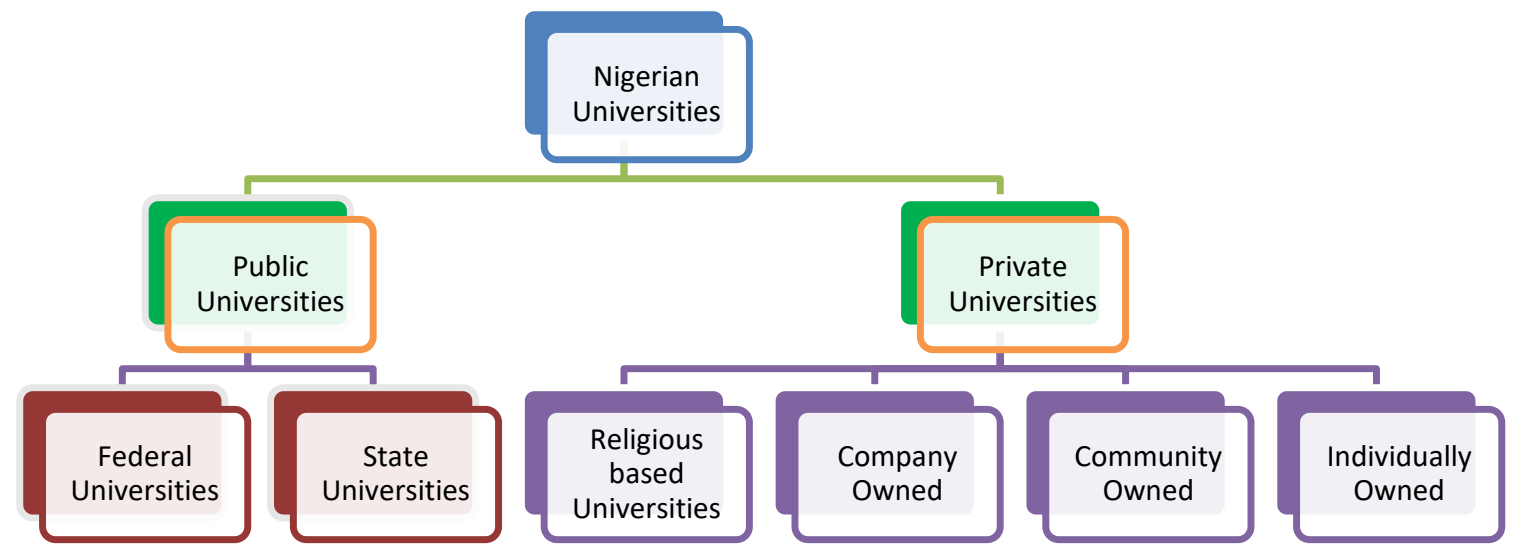

Figure 1. Ownership Classification of Universities in Nigeria

(Adapted from Mogaji, 2019)

\subsection{Overview of Public Higher Education in Nigeria -Universities}

\subsubsection{Federal Universities}

The first generation of federal universities were established from 1960 to 1970 (Salihu \& Hazri, 2015). Since then, more federal universities were established by Virtue Decree 46 by 1977 providing the federal government to establish universities across Nigeria (Iruonagbe, Imhonopi, \& Eghareva, 2015).

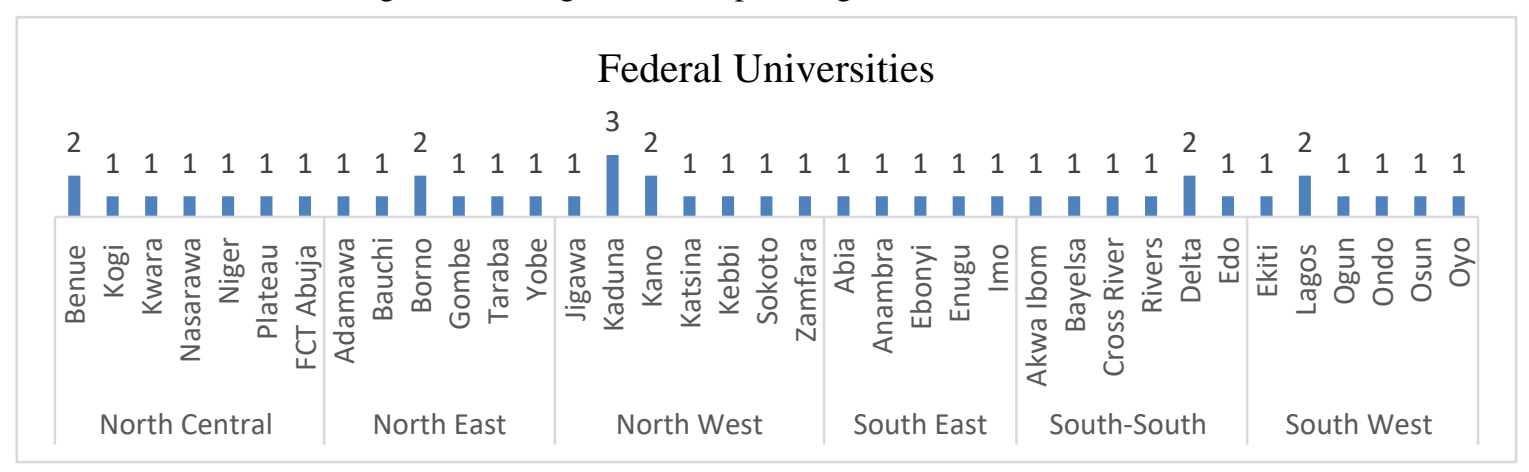

Figure 2. Nigerian Federal Universities Across the Geopolitical Zones, States and FCT, 2020

Source: National Universities Commission, http://nuc.edu.ng/, last accessed on $26^{\text {th }}$ Decmber, 2020.

Figure 2 shows there are 44 federal universities across Nigeria as of December, 2020. As highlighted by Ejiogu and Sule (2012), federal universities are considered among the most prestigious universities in the country. These universities were established in strategic locations to facilitate access to education for Nigerians. Okoroma (2007) also explained federal universities are under the control of the Federal Ministry of Education. Despite lack of funding, 
federal universities receive income from other sources such as donor agencies thereby enabling them to establish a sound internally generated revenue base for funds supplement from the federal government (Ejiogu and Sule, 2012).

\subsubsection{State Universities}

State universities are established by individual States of Nigeria (Mogaji, 2019). The first State university in Nigeria is Rivers State University of Science and Technology established in 1979 (NUC, 2020). According to Dimunah (2017), State universities were established in response to the growing pressure of students from each states who fail to get admitted in to federal universities. Nyewusira (2014) asserted that the development of state universities was predicated on the Constitution of the Federal Republic of Nigeria in 1979, indicating state government have powers to establish state own universities. Furthermore, the same author noted there are clear patterns in the establishment of state universities for political esteem.

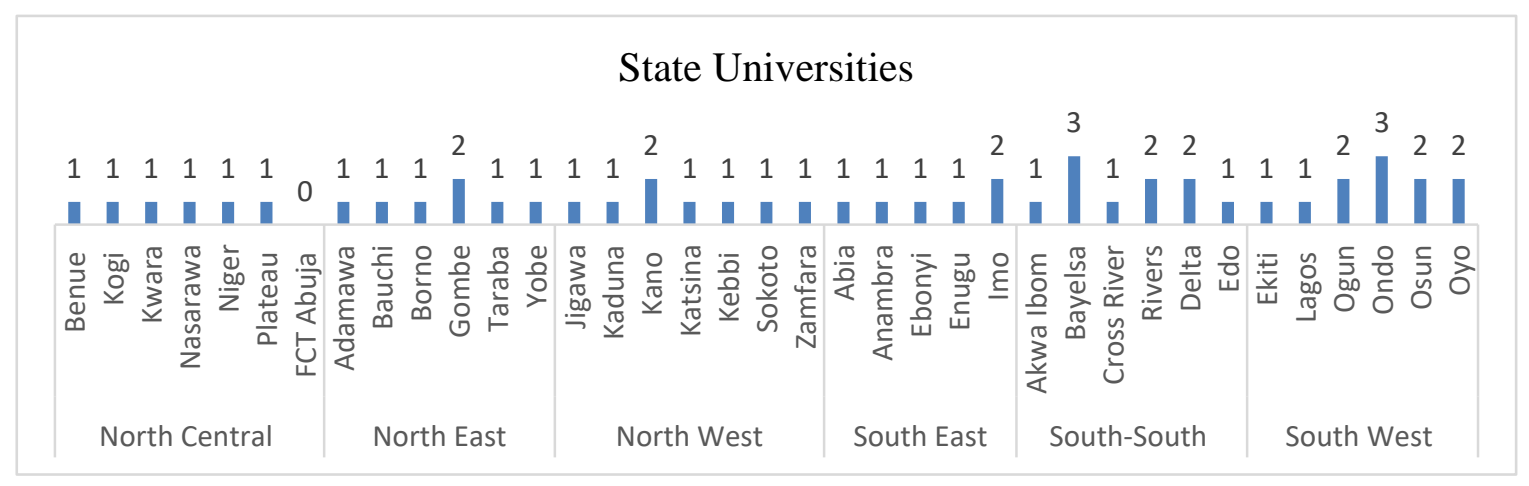

Figure 3. Nigerian State Universities across the Geopolitical Zones, States and FCT

Source: National Universities Commission, http://nuc.edu.ng/, last accessed on $26^{\text {th }}$ December, 2020.

Currently, there are 48 state universities in Nigeria as shown in Figure 3. According to Mogaji (2019), state universities are not often well funded compared to federal universities since their funding depends on education budgetary allocation from their state goverments. In relation to this, Ahmed (2015) noted a disparity between federal and state universities regarding funds and resources from the proprietors, since state universities have insufficient internally generated revenue and mostly rely on the state government for funds.

\section{Private Higher Education in Nigeria-Universities}

Nigeria is one of the countries in Africa with the biggest and most comprehensive higher education systems (Obasi, 2007). Over the years, the higher education system in Nigeria underwent a considerable amount of growth and diversification to cope with modern centres of learning, influenced by various factors such as globalization, internationalization, and digitization (Obasi, 2007). Moreover, the establishment of private universities in Nigeria was mainly due to the lack of capacity of public universities to accept students seeking admission to higher education institutions (Okoro \& Okoro, 2014; Salihu \& Hazri 2015). The establishment of private universities in the country attempt to provide equitable access to higher education institutions in places with limited access. Hence, Omomia, and Babalola (2014) argued that the idea of private higher education in Nigeria is a process of education deregulation towards aiding higher education institutions to become self-managed through privatization. The same authors mentioned Igbinedion University, Okada as the first licensed private university located in southern Nigeria. Yet, issues on educational imbalance particularly between northern and southern Nigeria are apparent (Akindele, 2013).

\subsection{Development of Private Higher Education in Northern Nigeria-Universities}

Northern Nigeria has an estimiated population of over 100 million (Africa.com, 2019) and comprises 21 of 36 states in the nation (Lubeck, 2014). The higher education system in northern Nigeria is known to be less-endowed financially in addition to scarce development capital for being the most underdeveloped region in the country (Olaiya, 2015). The development history of private higher education in northern Nigeria started in 2003 with the American University of Nigeria Yola as the first private university in the region. Two years later, another four universities emerged namely Al-hakima University Ilorin, Al-Qalam University Katsina, Bingham University Karu Abuja, and Kwararafa University Wukari Taraba state. As of December, 2020, there are 16 private universities in the northern region with 11 at north-central, 3 in the northwest, and 2 in the northeast compared to 63 universities in the entire southern part which also have three geo-politcal zones. 


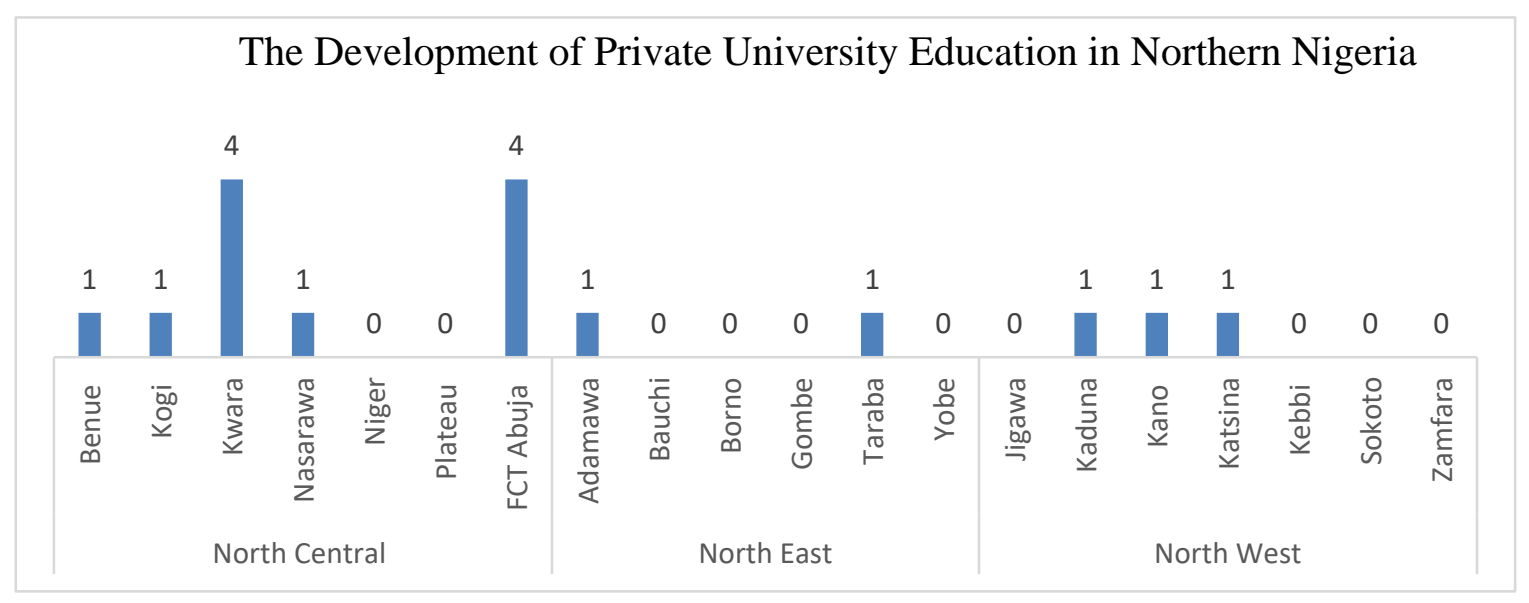

Figure 4. Distribution of Private Universities in the Northern States

Source: National Universities Commission, http://nuc.edu.ng/, last accessed on $26^{\text {th }}$ Decmber, 2020.

As shown in Figure 4, there are 16 private higher education institutions (universities) established in northern Nigeria. In particular, the distribution of private universities across states is 68.7 per cent in north-central, 12.5 per cent in the northeast, and 18.75 per cent in the northwest (NUC, 2020).

\subsection{Development of Private Higher Education in Southern Nigeria- - Universities}

There are more private higher education institutions (universities) in the southern Nigeria, predominantly in the southwest geo-politcal zone than in the northern region (NUC, 2020). Ahunanya and Osakwe (2012) suggested that most private universities prefer the southern region more due to the unavailability of a comprehensive education development link between both regions historically. According to the data from National University Commission 2020, the development history of private higher education precisely universities started 20 years ago in southern Nigeria with the establishment of Igbinedion University in Okada, Edo State in 1999 followed by Babcock University, Ileshan Remo, Ogun State, and Madonna University, Okija, Anambra State in the same year.

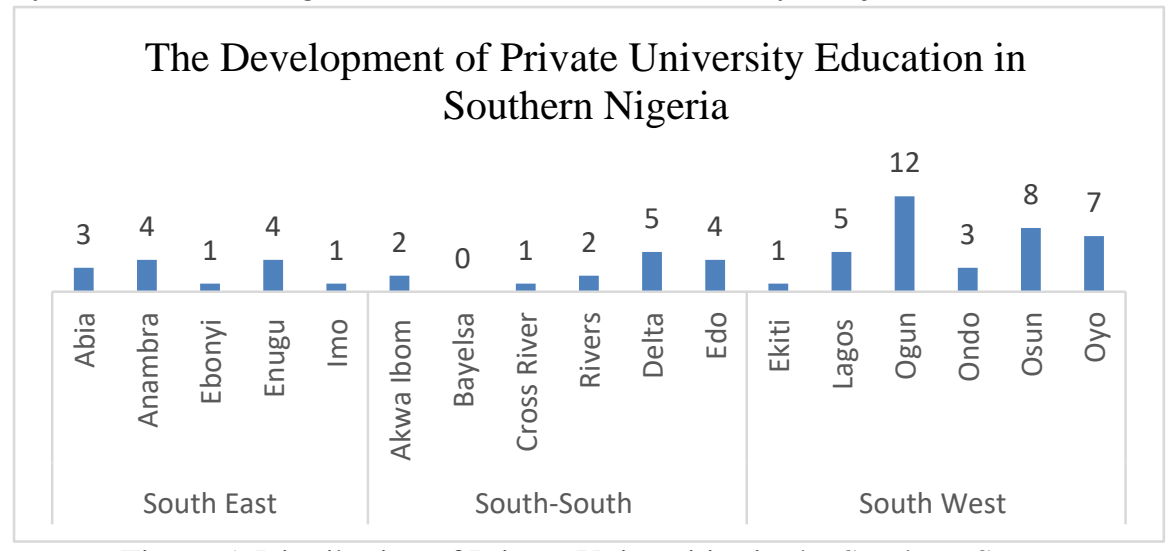

Figure 5. Distribution of Private Universities in the Southern States

Source: National Universities Commission, http://nuc.edu.ng/, last accessed on $26^{\text {th }}$ Decmber, 2020.

Figure 5 shows there are 63 private universities in southern Nigeria as of Decmber, 2020. The southwest region has the most private universities at $36(57.1 \%)$, followed by south-south at $14(22.2 \%)$, and southeast at $13(20.6 \%)$, compared to 16 private universities in the entire northern region despite been the most populous region in the country (NUC, 2020). Thus, as a result of establishing more private universities in the south, the imbalance between northern and southern Nigeria continues to widen (Akindele, 2013).

\section{The Synthesis of Higher Education in Nigeria - Universities}

Higher education is considered as one of the major developments in Nigeria, due to the belief of its capability to produce highly educated individuals who can play important roles in promoting economic development. Despite facing challenges such as inadequate funding and lack of proffesional workforce, an increase in average regional growth concerning student enrollment and the number of universities are witnessed across Nigeria (Akinyemi and 
Bassey, 2012). For example, the emergence of private universities in the country contributes to addressing the existing challenges of access among the Nigerian higher education system thereby promoting education to continuously be a driving factor to the country's growth and development (Iruonagbe et al., 2015).

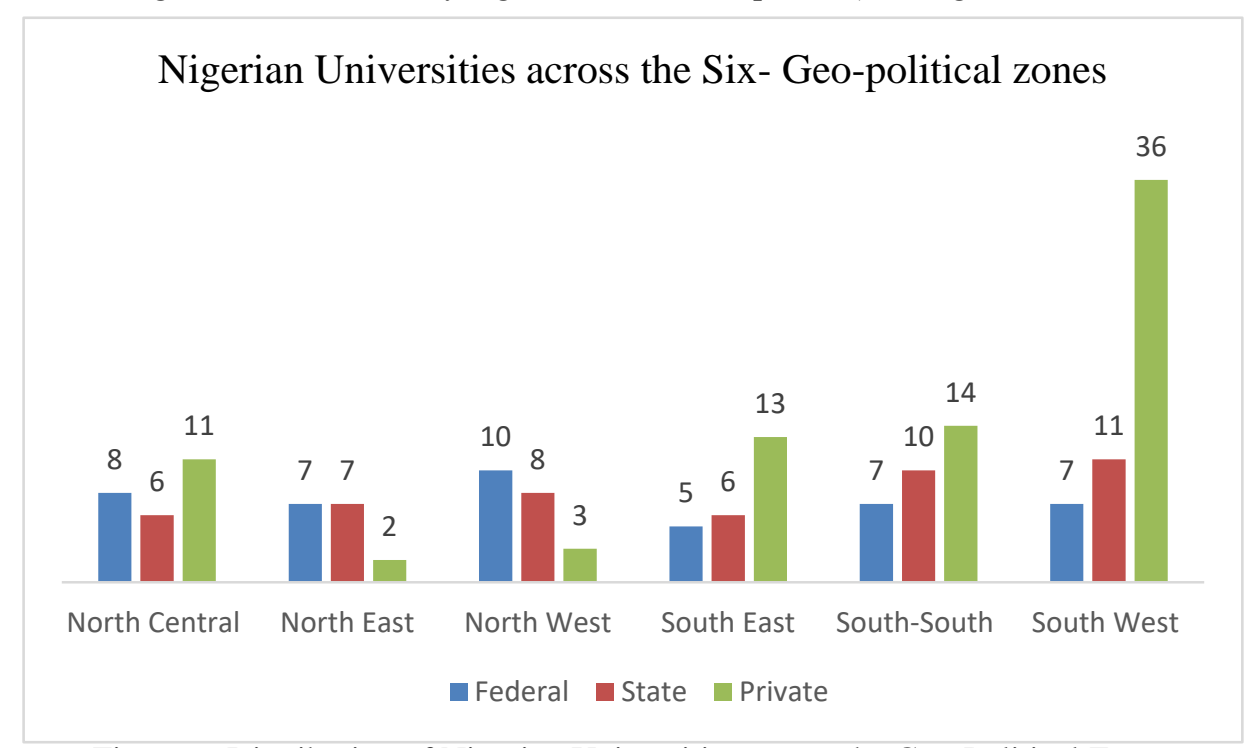

Figure 6. Distribution of Nigerian Universities across the Geo-Political Zones

Source: National Universities Commission, http://nuc.edu.ng/, last accessed on $26^{\text {th }}$ Decmber, 2020.

Figure 6 shows the distribution of all universities across the six geo-political zones Nigeria. As of December, 2020, there are 62 universities in the northern region with 25 in the northcentral, 16 in the northeast, and 21 in the northwest. Comparatively, with 109 universities in the southern region with 24 in southeast, 31 in south-south, and 54 in southwest. Apart from universities, there are also 128 approved Polytechnic and 117 Colleges of Education as of 2015, making Nigeria the largest higher education system across Africa (Iruonagbe, Imhonopi, \& Eghareva, 2015).

\subsection{Emerging New Private Universities in Northern Nigeria as of December 2020.}

A renowned private company in Kano, northwestern Nigeria (Figure 4) known as Azman Group announced the development of Azman University Kano (AUK) with the inauguration of a 10-man implementation committee overseeing the implementation earlier on $28^{\text {th }}$ July 2019 (https://twitter.com/AzmanAir/status/ 10 ${ }^{\text {th }}$ August 2019). Similarly, according to the Punch newspaper reports, Aliyu Magatarkda Foundation is set to establish a private university in Sokoto state, northwest Nigeria (Figure 4). The new university is proposed to be named the Northwest University of Science, and if successfully established, becomes the first science focus private university in the entire northern Nigeria. (Punch, $21^{\text {st }}$ August 2016).

Furthermore, the National Universities Commission (NUC) reported that a delegation from the Katagum Emirate Council Bauchi State northeast Nigeria (Figure 4) presented a proposal and letter of intent to the commission for the establishment of a community-based private university in Azare Bauchi state (twitter.com/OfficialNUC/status- $10^{\text {th }}$ October 2019). Interestingly, it will be the first community-based university in northern Nigeria upon successful establishment. According to reports from the Tribune newspaper on $14^{\text {th }}$ November 2019, NUC through the director of private universities establishment has approved a private university named -Khadijah University Majiya (KUM), in Jigawa state in northwest Nigeria (Figure 4). The newspaper reported the proposed university has completed 10 out of 14 formal stages to obtain operational license according to the director of private universities establishment (Tribune, $21^{\text {st }}$ November 2019). Recently, The Islamic Movement of Izalatil Bidi'a Wa Ikamatus Sunnah (JBWIS) secured interim approval to establish As-Salam International University in Hadejia in Jigawa state (Figure 4) (tropics.ng, 2020). Upon successful establishment, it will be the first religious-based university in northern Nigeria. Jigawa state has no private university prior to this.

\section{Private and Public Universities across the States}

For several decades, public universities have dominated the higher education landscape in Nigeria but failed to cope with admission pressure evidently since the 1990s (Iruonagbe, Imhonopi, \& Eghareva, 2015; Salihu \& Hazri 2015). Besides, federal universities in Nigeria are poorly funded and lacking adequate resources (Dimunah, 2017). The 
same author also claimed that the federal university administrators are not happy with the lack of funding which contributes to the downfall of Nigerian federal universities. This means that poor governance is one of the factors that influence the underperformance of the public higher education sector in Nigeria. According to NUC as of Decmber, 2020, there are 171 universities in Nigeria, namely 44 federal universities, 48 state universities, and 79 private universities as presented in Figure 7.

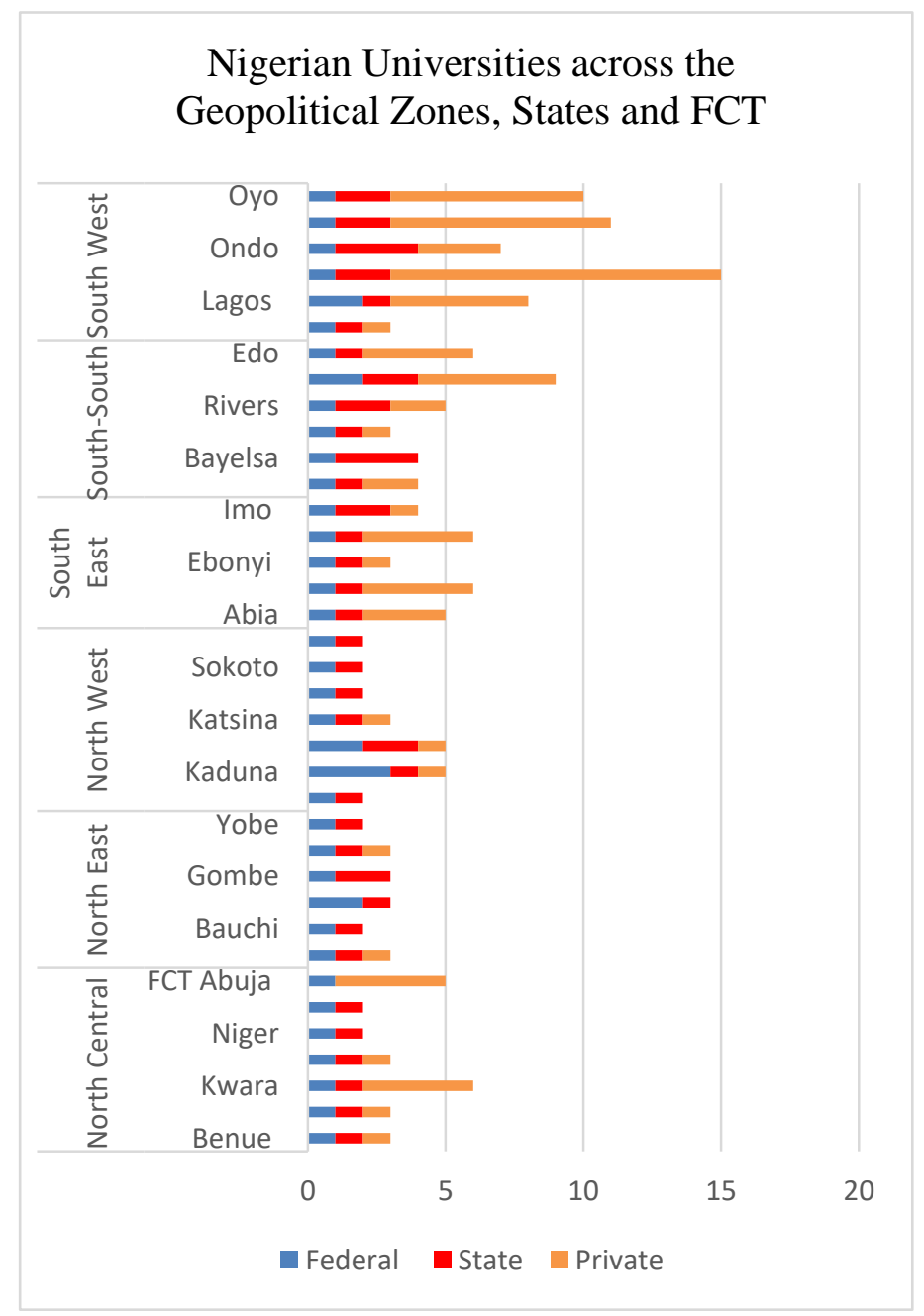

Figure 7. Distribution of Universities across the Nigerian States

Source: National Universities Commission, http://nuc.edu.ng/, last accessed on $26^{\text {th }}$ Decmber, 2020.

Figure 7 shows a relative balance in the distribution and number of public and private universities across the state. All states in Nigeria have federal and state universities except FCT have no state university. On a state level, there are still some states without or emargining private universities including Niger, Plateau, Borno, Gombe, Yobe, Kebbi, Zamfara, and Bayelsa (Mogaji, 2019; NUC, 2020).

\subsection{The Need for Private Higher Education in Nigeria}

Globalization has influenced the educational trends causing higher education to move forward and cope with changes in global development (Akindele, 2013). In Nigeria, the need for private higher education stems from several major issues including the inability to meet access demands in higher education and the degrading quality of university graduates in the country (Akindele, 2013). Furthermore, demographic changes and transitions contributed to the need for private higher education in the country just like the scenario of many south-east Asian countries (Salihu, 2020). The continuous high population growth (or increasing population) is the current demographic issue threatening equal access to higher education (Etebong, 2018). Also, gender discrimination is considered as one of the major hindrances in access to higher education (Mahabub, 2014). As highlighted by Olaiya (2015), education needs in Nigeria are essential particularly to address lack of access to higher education, lack of staffing needs, and lack of funding and 
resources, thereby creating more demands for private higher education in the country. Thus, the requirement for private higher education in Nigeria stems from the necessity to pursue global competitiveness and addressing education issues in the country.

\subsection{Challenges of Private Higher Education in Nigeria}

Similar to other developments in different fields, the development of private higher education in Nigeria also faces certain challenges. Atanda and Adeniran (2017) highlighted the challenges confronted by private higher education in Nigeria are more complex due to a combination of limited access to grants, increased cost, decreasing quality, and inflexibility in course selection. Similarly, Ahunanya and Osakwe (2012) added these challenges can be summarized as funding, staffing, and lack of infrastructural development. Ajadi (2010) suggested private universities must consider certain challenges ahead including courses offered by public universities, limited academic and other staff, the affordability of tuition fees, and the quality of education. Furthemore, another major challenges in the development of private higher education in Nigeria include lack of awareness and orientation, inadequate human resources, and cost of operation.

\section{Recommendations and Conclusion}

Education is one of the key drivers of economic development and sustainability worldwide. Various strategies focusing on improving the education quality and systems become an important part of national goals in several countries across the globe. In particular, improving access and quality of higher education become a necessity in different countries. Higher education institutions are considered as producers of knowledge and the need for higher education learning is growing. Futhermore, higher education also contributes to social equality and promotes economic security. Thus, higher education is a significant contributor to long term economic growth and development.

Currently, there are more private universities than federal universities in Nigeria. However, most of the private universities are in the southern region while only a few in the northern part. Therefore, this study recommends the Nigerian government and policymakers to focus on developing policies, programs and launching initiatives such as emphasizing on improving its infrastructural facilities that will lead to the emergence of more private universities in the northern region. Policymakers should also consider to increase funding for public universities as well as re-evaluating and improving higher education programmes. The government could also encourage and support public universities to explore various alternatives to generate funds besides tuition fees.

\section{References}

Abdulraheem, I., \& Muammed, A. (2014). Corporate Governance in Nigerian Higher Education: Issues and Challenges. European Journal of Business and Management, 6(2), 221-228.

Agboola, B. M., \& Ofoegbu, F. I. (2010). Access to University Education in Nigeria: A Review. Nigeria: University of Benin.

Ahmed, S. (2015). Public and private higher education financing in Nigeria. European Scientific Journal, 11(7), 92-109.

Ahunanya, S., \& Osakwe, T. (2012). Private Universities in Nigeria: Emergent Realities and Coping Strategies. Journal of Emerging Trends in Educational Research and Policy Studies, 3(5), 695-700.

Ajadi, T. O. (2010). Private Universities in Nigeria - the Challenges Ahead. American Journal of Scientific Research, 7, 15-24.

Akindele, I. (2013). Evolution of Private Universities in Nigeria: Matters Arising and the Way Forward. Educational Research and Reviews, 8(2), 41-50.

Akinyemi, S., \& Bassey, O.I. (2012). Planning and Funding of Higher Education in Nigeria: The Challenges. International Education Studies, 5(4), 86-95. https://doi.org/10.5539/ies.v5n4p86

Alemu, S. K. (2018). The Meaning, Idea, and History of University/Higher Education in Africa: A Brief Literature Review. Forum for International Research in Education, 4(3), 210-227. https://doi.org/10.32865/fire20184312

Atanda, I. A. (2017). Towards the Effective Management of Private University Education in Nigeria. International Journal of Advanced Academic Research, 3(3), 7-24.

Azman Air, (2019). https://twitter.com/AzmanAir/status/1159875356389707776 Accessed pm 19th December 2019 
Dimunah, V. O. (2017). Underfunding of Federal University in Nigeria and Perceived Impact on Administration: An Exploratory Case Study. Thesis. Northeastern University.

Education.stateuniversity.com. (2019). Nigeria - Higher Education. Retrieved from https://education.stateuniversity.com/pages/1105/Nigeria-HIGHER-EDUCATION.html

Ejiogu, A., \& Sule, S. (2012). Sixty-Five Years of University Education in Nigeria: Some Key Cross Cutting Issues. Retrieved from https://files.eric.ed.gov/fulltext/ED567099.pdf Accessed pm 19th December 2019

Etebong, P. C. (2018). Demography in Nigeria: Problems and Prospects. Biostatistics and Biometrics, 5(1), 1-5. https://doi.org/10.19080/BBOAJ.2018.05.555654

Fabunmi, M. (2005). Historical analysis of educational policy formulation in Nigeria: Implications for educational planning and policy. International Journal of African \& African-American Studies, 4(2).

Iruonagbe, C. T., Imhonopi, D., \& Egharevba, M. E. (2015). Higher Education in Nigeria and the Emergence of Private Universities. International Journal of Education and Research, 3(2), 49-64.

Lemoine, P. A., Jenkins, W. M., \& Richardson, M. D. (2017). Global Higher Education: Development and Implications. Journal of Education and Development, 1(1), 58-71. https://doi.org/10.20849/jed.v1i1.253

Lubeck, P. M. (2014). Explaining the Revolt of Boko Haram: Demography, Governance \& Crisis in Northern Nigeria.

Retrieved

from https://www.wilsoncenter.org/sites/default/files/Lubeck_Demography\%2C\%20Governance\%20\%26\%20Crisis \%20in\%20Northern\%20Nigeria.pdf Accessed 19th December 2020

Mahabub, M. G. (2014). The Challenges of Access to University Education in Nigeria. International Conference on Economics, Education, and Humanities (ICEEH'14) Dec. 10-11, 2014 Bali (Indonesia).

Mense, E. G., Lemoine, P. A., Garretson, C. J., \& Richardson, M. D. (2018). The Development of Global Higher Education in a World of Transformation. Journal of Education and Development, 2(3), 47-60. https://doi.org/10.20849/jed.v2i3.529

Mogaji, M. E. (2019). Types and Location of Nigerian Universities. Research Agenda Working Papers, 7, 92-103. https://doi.org/10.31124/advance.9722618.v1

National Universities Commission, (2019). https://twitter.com/OfficialNUC/status/1182211309523349504 Accessed pm 19th December 2020

National Universities Commission. (2020). Nigerian Universities. Retrieved from http://nuc.edu.ng/ Accessed December, 2020

Nyewusira, B. N. (2014). Politics and the Establishment of Public Universities in Nigeria: Implications for University Education. Journal of Education and Practice, 5(19), 171-179.

Obasi, I. N. (2007). Analysis of the Emergence and Development of Private Universities in Nigeria (1999-2006). JHEA/RESA, 5(2\&3), 39-66.

Okoro, N. P., \& Okoro, E. O. (2014). Time and Change: Development of Private Universities in Nigeria. International Journal of Business and Social Science, 5(9), 186-192.

Okoroma, N. S. (2007). The Supervisory Role of the National Universities Commission and the Management of Universities in the South-South Zone of Nigeria. Educational Research Quarterly, 34-57.

Olaiya, T. A. (2015). Expanding Private Higher Educational Institutions in Africa: Implications for Good Governance. British Journal of Education, 3(12), 9-28.

Omomia, O. A., Omomia, T. A., \& Babalola, J. A. (2014). The History of Private Sector Participation in University Education in Nigeria (1989-2012). Research on Humanities and Social Sciences, 4(18), 153-162.

Punch Newspaper Nigeria (2019). https://punchng.com/sokoto-gets-first-private-varsity/ https://punchng.com/sokoto-gets-first-private-varsity/ Accessed June 2020

Salihu, M. J. (2020). Demographic Change and Transition in Southeast Asia: Implications for Higher Education. Universal Journal of Educational Research, 8(2), 678-688. https://doi.org/10.13189/ujer.2020.080241

Salihu, M. J., \& Jamil, H. (2015). Achieving Equality of Educational Opportunity on Access to University Education in Nigeria: A Case of Policy Implementation. Hiroshima University Institutional Repository, 17(2), 3-22. 
Salihu, M. J., \& Jamil, H. (2015). Policy of universal basic education in Nigeria: An examination of its effectiveness on implementation and management. American International Journal of Contemporary Research, 5(6), 147-155.

Salihu, M., Jamil, H., \& Ismail, A. (2015). Exploring Institutional Policies towards Achieving Macro Policy of Equal University Admission: A Case of a Selected University in Northwest Nigeria. International Research in Higher Education. https://doi.org/10.5430/irhe.v1n1p170

Tribune Newspaper Nigeria (2019). https://tribuneonlineng.com/nuc-approves-first-private-university-in-jigawa/ Accessed pm 19th December 2020

Tropical

https://tropics.ng/2020/10/14/all-you-need-to-know-about-as-salam-international-university-in-hadejia-jigawa/ accessed December 2020

Turner, D. A. (2011). Quality in Higher Education. The Netherlands: Sense Publishers. https://doi.org/10.1007/978-94-6091-684-7

\section{Copyrights}

Copyright for this article is retained by the author(s), with first publication rights granted to the journal.

This is an open-access article distributed under the terms and conditions of the Creative Commons Attribution license (http://creativecommons.org/licenses/by/4.0/). 